principles represent a reflexive order of assembly, in which different theoretical elements like postcolonial critique, marxist and feminist theory are both interlocking and simultaneously questioning each other.

The biographies are presented as a mediation between the structural dominant logic of identity and the potentialities of agency', becoming transparent through 'dialectical pictures' of the past in the account of the present. On this level, Gutiérrez Rodríguez discusses the individual ways in which migrant women deal with social and discursive constraints. By taking this perspective, she shows the ways in which the moment of constraint sits alongside the desire for freedom. This is articulated in the complex sociability (Vergesellschaftung) that emerges on one side, through the intersection of different structures of domination and on the other, through the collective and individual desires of the women. It is in this context that Gutiérrez Rodríguez situates the different strategies of the women within the notion of a 'politics of location'. As an answer to the institutional and social economies of othering, as Gutiérrez Rodríguez shows in her chapter on 'Turkeyfication', the women named strategies in which they try to counter being positioned as the other by not assuming the place of the Same. Instead, they question these two poles and create through their individual skills and collective political or social practice new ways of situating themselves in movement without forgetting the effects of border and migration regimes.

Gutiérrez Rodríguez highlights the biographical contingency in the formation of subjectivity. Here biography includes concrete geographical and political contexts that are themselves seen as an effect of a specific balance of power. Thus, subjectivity is to be understood as the configuration of manifold power relations, as a cross-section of historical, institutional, social and symbolic processes.

doi:10.1057/palgrave.fr. 9400170

Hito Steyerl

\title{
Negotiating citizenship: migrant women in Canada and the global system
}

Daiva K. Stasiulis and Abigail B. Bakan; Palgrave Macmillan, 2003 Basingstoke, UK and New York, $£ 50.00$ ISBN: $0-333-68960-7$ ( Hbk)

Citizenship, conceptualized as both a relationship and contested process, is this book's organizing theme. The authors' thesis that citizenship is negotiated and uneven, with the nation-state remaining as a primary arbiter and organizer of access to 'major fundamental rights', is skillfully argued using the case of migrant women from the Philippines and the West Indies working as live-in caregivers or nurses in Canada. The case of Canada is particularly apt as a prominent receiving 
country of international migrants, where multiculturalism as ethic, practice and policy frames the building of its contemporary social formation. Yet despite the optimism suggested by a Multicultural Act with principles of equal access to state resources and opportunities and a 'celebration' of diversity, the story of the women in this book tells a less than rosy picture of the state management of such diversity. These are women trapped in a complex web of economic, political and social processes, operating at various scales that construct such women as outside the Canadian 'collectivity' and deny them full citizenship rights. But the book is more than a case study of these migrant women and their fortunes in Canada. Its strength lies in its careful delineation of the entanglements of global flows of capital and people, structural adjustments and uneven economic development that lead to 'forced' migration, transnational connections between migrants and their sending states, immigration policy and its links with state political economy and service provision, and finally the gatekeepers and employers that shape the particularities of the work that migrants do. Ultimately, it is the entrenchment of neo-liberalism that acts as 'fertile ground' for the emergence of 'conditional' citizenship of women migrants who, as described in this book, find themselves vulnerable to exploitation and discrimination as racialized workers in the caring industry. Nevertheless, as the book goes on to show, legal cases and advocacy organization action show that women migrants and their supporters are chipping away at the structures and practices that produce their vulnerability and maintain barriers to citizenship rights.

The chapters of the book take the reader through the authors' 'multidimensional' methodological approach, starting with an account of the creation of gendered pools of migrant labour in the West Indies and the Philippines following structural adjustment and underdevelopment, and ending with an analysis of 'dissident transnational citizenship' in the form of international solidarity movements supporting Filipino migrants seeking citizenship rights. The chapters in between the book ends draw on interviews with gatekeepers of women's entry into Canada and their access to specific employment situations, particularly those entering under the Live-in Caregiver Programme, and questionnaire survey research with workers from each national grouping in both domestic service and nursing work that seeks to explore the women's experiences as migrant workers. In both these occupations, a hierarchy is observed in desirability of employees, which affects their equal inclusion in the Canadian collective. Women from the West Indies are less likely than Filipina women to get work as a live-in caregiver, and more likely to be discriminated against in nursing in the form of being given the least desirable type of work and shifts. A further chapter turns to the legal citizenship and legal strategies used in challenging the absence of full citizenship rights for foreign domestic workers. Throughout the book, the meshing of Canadian immigration policy, the increased 'need' for caregivers emerging from inadequate service provision in a neo-liberal climate, and the poverty of sending countries is 
emphasized in setting the scene for the employment conditions and opportunities for women migrant workers. The Live-in Caregiver Programme, which can result in landed immigrant status if a caregiver works for two out of three years in Canada as a livein caregiver, is heavily criticized for its lack of adequate protection for caregiving employees who are potentially highly exploitable in the homes where they work.

The book is important in its meticulous setting out of the contextualization of migrant women's experiences in global and local processes. This allows the authors to develop their argument that 'national citizenship is conditional, partial, particularistic and generates inequality' (p. 165). That the two groupings portrayed in the analysis are racialized women from countries whose economic development is closely tied to globalization and uneven development will be of no surprise to those who work in the field of migration studies. Similar scenarios are observed in other 'developed' countries in the global system. The authors remark on the women's display of 'tremendous courage in contesting the unjust laws and social arrangements that have threatened to imprison them' ( $p$. 167). This comment sums up both the strengths and weaknesses of the book. Women are granted some agency, working collectively and through legal action to contest their conditional and precarious citizenship. Neither are they reduced to individual decision-makers but rather are located in the complex arena of political economies, state immigration policy practices, and local workplace politics. However, the survey methodology and its small numbers - for this type of research - limits the claims the authors can make. I am not arguing against the important message and theoretical contribution the authors offer, but I would have liked to know more about these women, their families, the households where they worked and ambiguities in their relationships with the state and employers. While deeply contextualized in the interweaving of global and local processes, I found the women's voices curiously absent. Its bleak view of the women's situations leaves no room for what is surely a more nuanced picture. Nevertheless, with this proviso, the book is a valuable addition to the growing collection of feminist scholarship addressing the notion of citizenship.

Isabel Dyck

doi:10.1057/palgrave.fr. 9400171

\section{Servants of Globalization: Women, Migration, and Domestic Work.}

Rhacel Salazar Parreñas; Stanford University Press, 2001 Stanford, CA, £12.95 ISBN: 0-80473922-6; (pbk); £40.00 0-8047-3921-8 (hbk)

Feminist scholars have pointed out that the process of globalization has had varying impact on men and women in both developing and developed countries. 